\title{
Characteristics and Moisture Sources of the Stable Isotopes in Precipitation at the Monsoon Marginal Region of North-Central China
}

\author{
Yiping Zhang\#, Junliang Xü*, Yafei Yan, Wei Su, Pengfei Luo, Hongfei Yu \\ College of Horticulture and Plant Protection, Henan University of Science and Technology, Luoyang 471023, China
}

Received: 20 August 2021

Accepted: 23 October 2021

\begin{abstract}
The stable isotopes in precipitation $\left(\delta \mathrm{D}\right.$ and $\left.\delta^{18} \mathrm{O}\right)$ are important source signatures for understanding the hydrological cycle and paleoclimatic reconstruction, but little is known about these characteristics in monsoon marginal region of China. Here, 160 precipitation samples were collected in 2014 (AprilOctober) at alpine ecosystem, a representative site in the monsoon to non-monsoon transitional area of north-central China. The Local Meteoric Water Line was $\delta \mathrm{D}=(7.95 \pm 0.16) \delta^{18} \mathrm{O}+(15.79 \pm 1.77)$ $\left(R^{2}=0.988\right)$, which had a similar slope but higher intercept than that of the Global Meteoric Water Line, indicating the precipitation in this area is mainly sourced from the ocean surface transported via monsoons. Additionally, the secondary evaporated water by continental recycled moisture was identified by the significantly higher $d$-excess value $(16.09 \%$ ). Backward trajectories by HYSPLIT model indicated seasonal moisture transport changes, which mainly from the Westerly winds in April, the Pacific Ocean in July, and the Indian Ocean in September. Positive temperature-isotopic signature effect was observed in the snow season (before mid-May); however, precipitation amount effect was observed in the monsoon season (June-August), and neither effect was significant in the whole year. These findings suggest the precipitation stable isotopes can be potentially utilized to reconstruct the precipitation signals in this region.
\end{abstract}

Keywords: stable isotopic signature, $d$-excess, secondary evaporation, Hybrid Single-Particle Lagrangian Integrated Trajectory (HYSPLIT) model, alpine ecosystems

\section{Introduction}

The stable isotopes of hydrogen and oxygen in precipitation $\left(\delta \mathrm{D}\right.$ and $\left.\delta^{18} \mathrm{O}\right)$ are useful for hydrological observations and simulations $[1,2]$. As natural tracers,

\# These authors contributed equally to this work *e-mail: xj1_790626@126.com stable isotopes can be utilized to identify water sources [3] and explore hydrological processes, which provide a better understanding of the atmospheric moisture cycle [4] and paleoclimatic reconstruction [5]. These applications are based on the variations in isotopic compositions of precipitation caused by isotopic fractionations (equilibrium and non-equilibrium fractionations) that occur during water evaporation and condensation, because the heavier water molecules 
preferentially remain or pass to the liquid or solid phase, instead of the vapor phase [6]. Therefore, the heavy isotope composition of precipitation is affected by the temperature and humidity of water vapor condensation, the air mass history and trajectory, the degree of secondary evaporation, and the moisture exchange with the environment [7-9].

For global precipitation, $\delta \mathrm{D}$ and $\delta^{18} \mathrm{O}$ exhibited a close linear relationship under equilibrium fractionation conditions, defined by Craig [10] as the Global Meteoric Water Line (GMWL: $\delta \mathrm{D}=8 \delta^{18} \mathrm{O}+10$ ). However, the slopes and intercepts for Local Meteoric Water Lines (LMWL) may differ from the global average due to differing local geographic and meteorological conditions $[11,12]$. Therefore, LMWL is recommended to accurately interpret the hydrological processes in a specific area $[13,14]$. Deuterium excess ( $d$-excess), defined by Dansgaard [15] as $d$-excess $=\delta \mathrm{D}-8 \delta^{18} \mathrm{O}$, is also a useful indicator for identifying moisture sources and sub-cloud processes [4]. Previous studies have also established the 'temperature effect' (positive isotope-air temperature relationship) and 'amount effect' (negative isotope-amount relationship) as two of the important meteorological factors that influence variations in the isotopic compositions of precipitation $[16,17]$. The temperature effect is significant in highand mid-high latitude interior continental regions while the amount effect is primarily noticeable in mid-low latitude oceanic and monsoon regions [18]. However, in transitional areas where the mixed moisture is transported from continental (especially in winter) and oceanic (i.e., convective rains falling in summer) air masses, the meteorological factors causing variability in the isotopic composition of precipitation are unknown [19]. Furthermore, whether the isotopic signature of precipitation in transitional areas is affected by a single or both effects throughout the year and if their effects vary in the different seasons remains unclear.

China, located in the Asian monsoon region, experiences distinct variations in its annual cycle and alternation between dry and wet seasons, resulting in highly complex stable isotopes in the precipitation due to seasonal air masses shifts between dry continental and moist oceanic water vapor [20]. Araguás-Araguás et al. [21] reported that the slope of LMWL in the southeast region of Asia, where the Asian summer monsoon has the strongest influence, is indistinguishable from the GMWL. In contrast, lower slopes and intercepts were observed in the semi-arid or arid climate regions located inland and controlled by dry continental polar air masses [12]; therefore, oceanic water vapor cannot be transported to this area by the Asian summer monsoon.

The temporal variability of the isotopic composition of precipitation in China, base on data from the Global Network of Precipitation (GNIP) and Chinese Network of Isotopes in Precipitation (CHNIP), has been supplemented by numerous local station-level studies $[22,23]$. In recent decades, the spatial variations of the stable isotopes in precipitation have been characterized at regional level (Tibetan Plateau) [2] and river basin level (Hei River) [24]. These studies revealed the significance of moisture transport from multiple oceanic sources (i.e. South China Sea, the Pacific and Indian Ocean) via monsoons and the contribution of recycled water to the continental interior. However, the stable isotopes in precipitation data at the ecosystem level are sparse and limited, especially for alpine ecosystems due to the difficulty in accessing these areas. Several studies focused on the importance of secondary evaporated water in alpine ecosystems water balances [3, 25, 26]. Zhang et al. [27] demonstrated that precipitation on the alpine ecosystems of the high mountains in the eastern Qinghai-Tibet Plateau was doubly controlled by monsoons and local water circulation, and the local water vapor produced precipitation with a significantly higher $d$-excess value $(34.70 \pm 5.55 \%)$ than the average $d$-excess value $(10 \%)$. However, few studies have been conducted in the alpine ecosystems distributed across north-central China, which is the transitional region for the monsoon climate to the non-monsoon climate. Precipitation source information in this alpine ecosystem could elucidate the water maintenance mechanisms in the mountainous regions of north-central China, the economic and cultural center of China.

This study obtained 160 precipitation samples collected from April-October 2014 in an alpine meadow on Luya Mountain, a representative site in the monsoon marginal area of north-central China. The site is located in the headwater catchment of the Fen River, which provides critical amounts of water to regional water systems. The objectives of this study were to (a) examine the seasonality of isotope signals in precipitation, (b) reveal the correlations between meteorological variables and precipitation isotopic compositions, and (c) determine the backward air mass trajectories to infer the different moisture source influences on the $\delta \mathrm{D}$ and $\delta^{18} \mathrm{O}$ variations in the alpine ecosystems precipitation. The results of this study could provide a better understanding of the stable isotope composition of precipitation in monsoon marginal areas and improve our perception of alpine ecosystems hydrological processes.

\section{Material and Methods}

\section{Study Area}

The Lvliang Mountain Range, an important mountain range on the northern margin of the Loess Plateau in China [28], is a watershed located between the Yellow and Fen (a tributary in the middle reaches of the Yellow River) Rivers (Fig. 1a). The Lvliang Mountain Range is a northeast-southwest trend with a length exceeding $400 \mathrm{~km}$, consists of a series of mountains with most peaks higher than $2500 \mathrm{~m}$ a.s.1., and has a significant effect on the regional climate. 


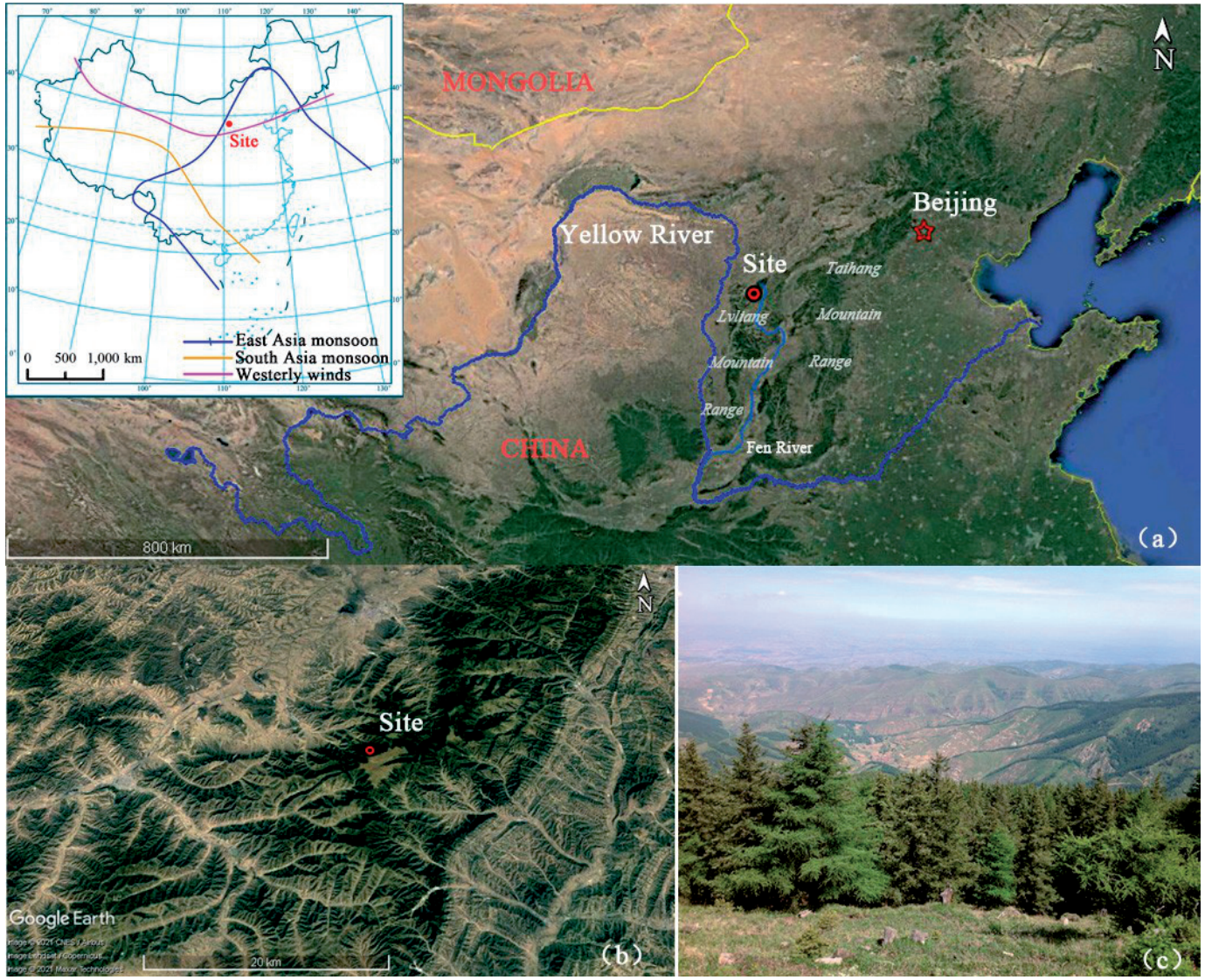

Fig. 1. Location of study site in North China a and b), and the study area landscape at the summit c). The insert map in a) depicted the extent of major air masses controlling the study area, which was cited from Araguás-Araguás et al., (1998).

Luya Mountain lies in the northern section of the Lvliang Mountain Range $\left(38^{\circ} 40^{\prime} \mathrm{N}-38^{\circ} 50^{\prime} \mathrm{N}\right.$, $\left.111^{\circ} 50^{\prime} \mathrm{E}-112^{\circ} 00^{\prime} \mathrm{E}\right)$ and is the headwater catchment of the Fen River. With interlacing mountains and valleys, Lvliang mountain ranges obstructs the inland penetrate of the East Asian summer monsoon [29], resulting in a significant precipitation decrease and rapid climate change from humid to semi-humid and semi-humid to semi-arid [30].

Our study site was located on the summit of Luya Mountain (2740 m a.s.1., 38 $43^{\prime} 47^{\prime \prime} \mathrm{N}, 111^{\circ} 50^{\prime} 16^{\prime \prime} \mathrm{E}$, Fig. 1b, c), which has a typical semi-humid temperate monsoonal climate, with long, cold, dry winters and short, warm, rainy summers [31]. According to the long-term average (1957-2013), the mean annual temperature at the base of the mountain $(1401 \mathrm{~m}$ a.s.l.) is approximately $5.2^{\circ} \mathrm{C}$, and the average annual precipitation is approximately $473 \mathrm{~mm}$, over $60 \%$ of which falls between June and September (Fig. 2).

\section{Precipitation Sample Collection}

Precipitation samples were obtained between April-October, 2014; however, not all samples could be collected immediately after each precipitation event ended due to site accessibility issues and the lack of field stations for lodging. From April-June, 15 event- based precipitation samples were collected, seven of which were snowfall. From July-October, 17 samples were collected at weekly or biweekly intervals, which included multiple rain events during the sampling period.

Two types of precipitation samples were obtained, rainfall and snowfall. The rainfall samples were collected via a rain collector comprised of a $6-\mathrm{cm}$ diameter funnel and a $100-\mathrm{ml}$ volume polyethylene bottle, and a ping-pong ball was placed in the funnel to avoid isotopic fractionation caused by water evaporation [20]. In this study, a rainfall event was defined as a rainfall depth of $0.1 \mathrm{~mm}$, which is sufficient for isotopic analysis [32]. For the snowfall samples, fallen snow samples were collected, transferred into plastic bags to reduce evaporation, and stored at room temperature for completely thawing. The rainfall and snowfall samples were transferred into clean, sealed $30 \mathrm{ml}$ polyethylene bottles and stored in a refrigerator at approximately $-4^{\circ} \mathrm{C}$. A total of 32 precipitation samples with five replicates each were collected.

Additionally, meteorological data, including precipitation amounts, air temperature, and relative humidity, were recorded at 30-min intervals near the study site (2740 $\mathrm{m}$ a.s.1.). A detailed description of the meteorological instrumentation utilized in this study can be found in Zhang et al. [33]. 

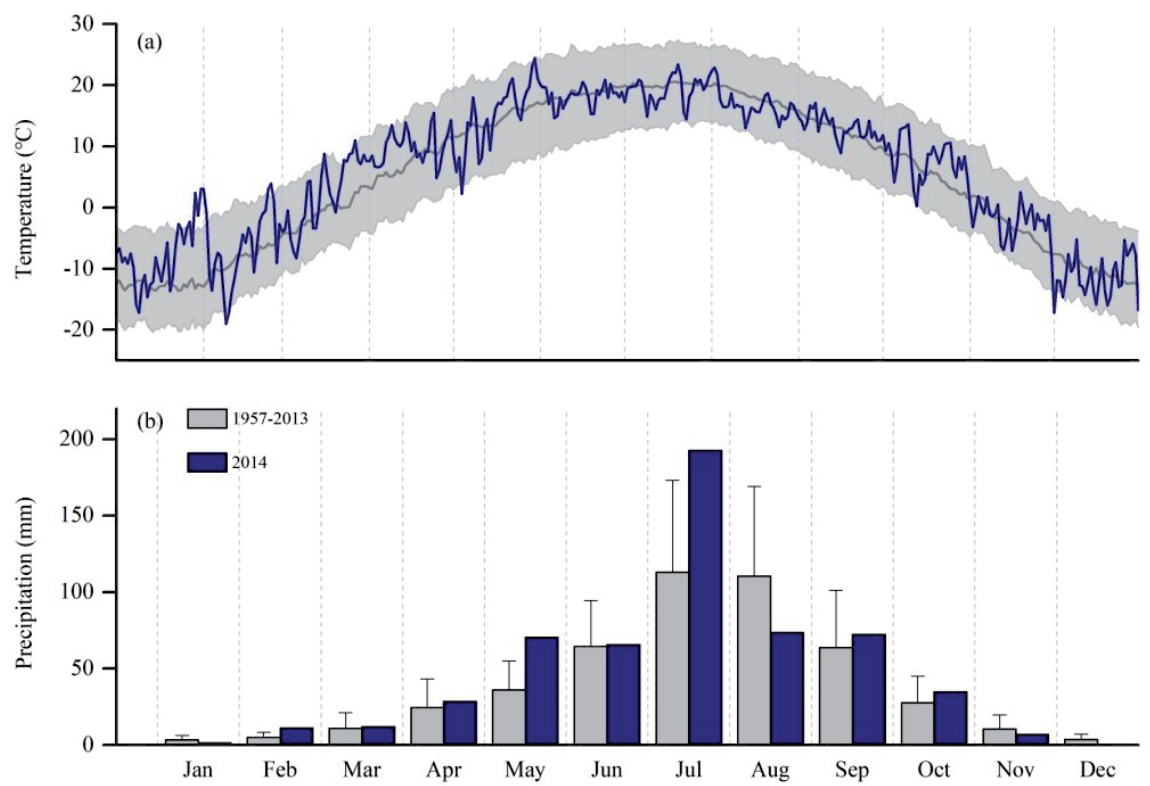

Fig. 2. Comparison of a) the mean daily air temperatures and b) the monthly sums of precipitation for the monitoring year of 2014 (blue) and the 1957-2013 average (light grey). Grey shading in a) indicates the mean minimum and maximum temperatures averaged over the 1957-2013 period. The data in b) represents mean \pm SD. Data was obtained from the nearest state meteorological station in Wuzhai $\left(38^{\circ} 55^{\prime} \mathrm{N}, 111^{\circ} 49^{\prime} \mathrm{E}, 1401 \mathrm{~m}\right.$ a.s.l., linear distance approximately $20 \mathrm{~km}$ north of the study site).

\section{Isotope Analysis}

All the $\delta \mathrm{D}$ and $\delta^{18} \mathrm{O}$ compositions were analyzed using an isotopic ratio infrared spectroscopy system (Model DLT-100, Los Gatos Research, Mountain View, CA, USA) at the State Key Laboratory of Earth Surface Process and Resource Ecology, Beijing Normal University, China. The laboratory standards were used and calibrated with reference to the Vienna Standard Mean Ocean Water (V-SMOW) [34]. The results were expressed as per mil (\%) deviations from the internationally accepted V-SMOW standard according to

$$
\delta(\% 0)=\left(\frac{R_{\text {sample }}}{R_{\text {standard }}}-1\right) \times 1000
$$

where $R$ represents the ration of the heavy to light isotope $\left({ }^{2} \mathrm{H} /{ }^{1} \mathrm{H}\right.$ or ${ }^{18} \mathrm{O} /{ }^{16} \mathrm{O}$ ratio). $R_{\text {sample }}$ and $R_{\text {standard }}$ are the isotope ratios $\left({ }^{2} \mathrm{H} /{ }^{1} \mathrm{H}\right.$ or ${ }^{18} \mathrm{O} /{ }^{16} \mathrm{O}$ ratio) in samples and the $\mathrm{V}$-SMOW. The measurement precision was $\pm 1.0 \%$ and $\pm 0.3 \%$ for $\delta \mathrm{D}$ and $\delta^{18} \mathrm{O}$, respectively.

\section{Statistical Analysis}

The months of June-August mark the peak activity of the monsoon in most part of China [20]. Thus, the observation period was divided into three phases: before the monsoon (April-May), during the monsoon season (June-August), and after the monsoon (SeptemberOctober).

The monthly or phase volume-weighted means of $\delta \mathrm{D}$ and $\delta^{18} \mathrm{O}$ in precipitation were calculated as follows:

$$
\delta p=\frac{\sum_{i=1}^{n} \delta_{i} \times P_{i}}{\sum_{i=1}^{n} P_{i}}
$$

where $\delta_{i}$ is the $\delta \mathrm{D}$ and $\delta^{18} \mathrm{O}$ of the $i$ th precipitation, and $P_{\mathrm{i}}$ is the amount of the $i$ th precipitation.

A one-way analysis of variance (ANOVA) was used to assess the temporal patterns of $\delta \mathrm{D}, \delta^{18} \mathrm{O}$ and $d$-excess in precipitation across the three phases (before, during, and after the monsoon season), after testing for residuals normality and variance homogeneity. The Fisher's Least Significant Difference (LSD) test was used for posthoc multiple comparisons.

To test the isotope-temperature and isotope-amount effects, the linear relationships between $\delta \mathrm{D}$ and $\delta^{18} \mathrm{O}$ and meteorological parameters (air temperature and precipitation amount) were analyzed using the Pearson correlation coefficient. The daily mean air temperature and precipitation amount were calculated for each sample interval, and all statistical analyses were conducted using SPSS (SPSS Inc., Chicago, IL, USA).

\section{Backward Trajectories for Moisture Sources}

To identify probable moisture sources and transport paths, air mass backward trajectories were analyzed by the Hybrid Single-Particle Lagrangian Integrated Trajectory Model (HYSPLIT version 4, HYSPLIT4) and based on 2.5-degree Meteorological National Centers for Environmental Prediction/National Center for Atmospheric Research ((NCEP/NCAR) reanalysis data [35]. This model has previously been used together with water isotope measurements to analyze moisture sources and isotopic signatures of precipitation, with 
considerable success $[32,36,37]$. The time period of 6-day (144-h) backward trajectories were modeled because the study site is far from any ocean [38]. The altitudes were set at $1500 \mathrm{~m}, 3000 \mathrm{~m}$, and $5500 \mathrm{~m}$ above ground level (approximately equivalent to 850, 750, and $500 \mathrm{hPa}$, respectively), as major horizontal moisture transport in this region is contained up to $1500 \mathrm{~m}$ a.s.1. [39], and at the same time to avoid any low-altitude topographical interferences [3].

\section{Results}
Isotopic Value Variations $\left(\delta \mathrm{D}, \delta^{18} \mathrm{O}\right.$ and $d$-excess) and LMWL

During the study sampling period, the $\delta \mathrm{D}$ and $\delta^{18} \mathrm{O}$ values (rainfall and snowfall samples) ranged from $-185.61 \%$ to $-18.50 \%$ and $-25.51 \%$ to $-4.59 \%$, respectively (Fig. 3, Table S1). The minimum monthly

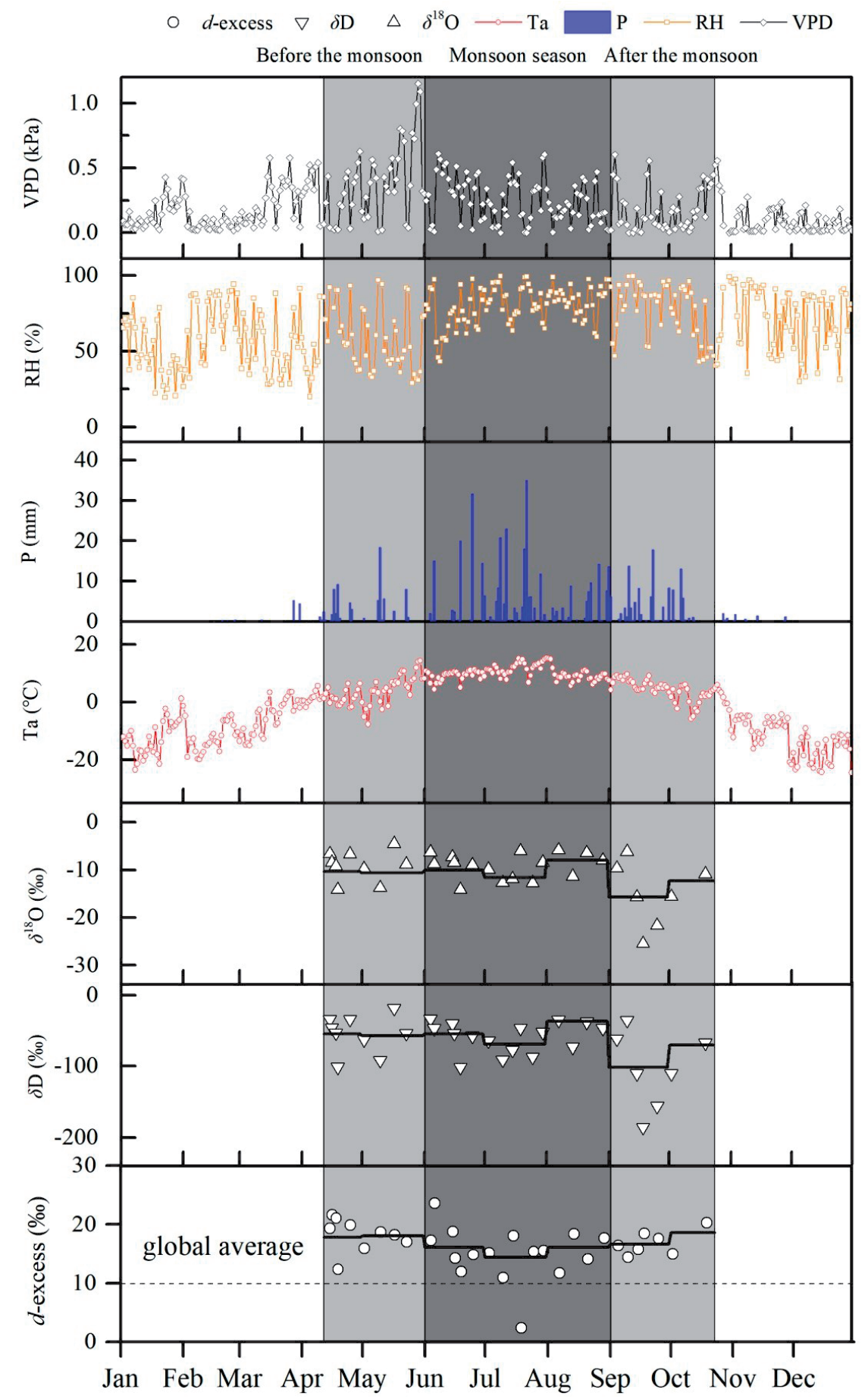

Fig. 3. Temporal precipitation isotope composition changes $\left(\delta \mathrm{D}, \delta^{18} \mathrm{O}\right.$ and $\mathrm{d}$ - $d$-excess and the corresponding environmental variables in the alpine ecosystem of Luya Mountain, China, in 2014. Ta: air temperature, P: precipitation amount, RH: relative humidity, VPD: vapor pressure deficit. 


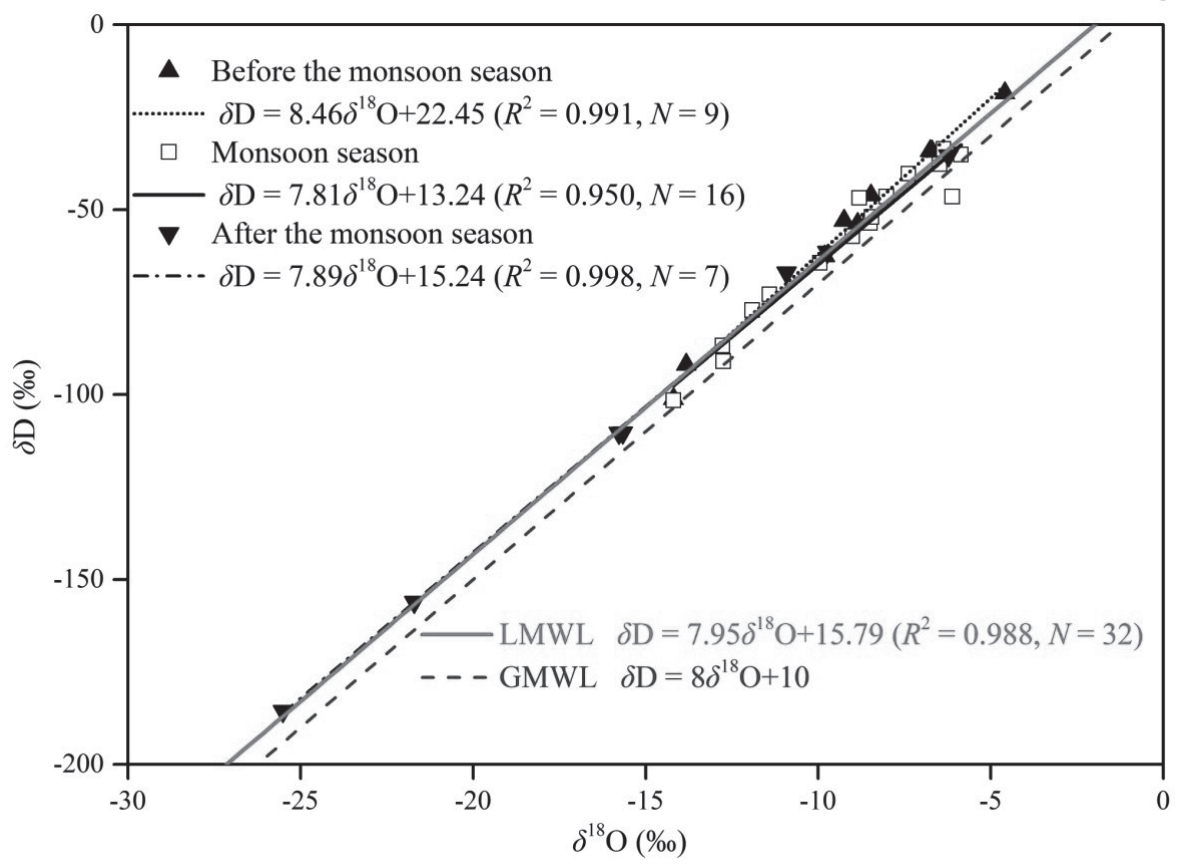

Fig. 4. Relationship between $\delta \mathrm{D}$ and $\delta^{18} \mathrm{O}$ of precipitation in the alpine ecosystem of Luya Mountain, China, in 2014. Red solid and blue dashed lines represent the Local Meteoric Water Line (LMWL) and Global Meteoric Water Line (GMWL), respectively. The three black regression lines are calculated separately for each phase, including soon (April-May), during the monsoon season (June-August), and after the monsoon (September-October). Add a descriptive label of the figure here.

weighted values were $-110.24 \%$ and $-15.86 \%$ for $\delta \mathrm{D}$ and $\delta^{18} \mathrm{O}$, respectively, and occurred in September, and their maximum values were $-48.71 \%$ and $-8.10 \%$, respectively, which occurred in August. The isotopic values were significantly lower after the monsoon season compared with the other two phases $(p<0.05$, Table S1). The mean $d$-excess value in the study area was $16.09 \%$, which is much higher than the global mean $d$-excess value of $10 \%$.

A strong linear relationship was observed between $\delta \mathrm{D}$ and $\delta^{18} \mathrm{O}$ in the LMWL (Fig. 4). The slope of LMWL was similar to the global average of 8; however, the intercept of LMWL herein is much higher than the GMWL.

\section{Temperature and Precipitation Amount Effects}

Owing to the significant mean air temperature differences between the rainfall and snowfall events, which were $8.0 \pm 4.0^{\circ} \mathrm{C}$ and $1.2 \pm 3.4^{\circ} \mathrm{C}$, respectively, the samples were divided into rainfall and snowfall types for temperature effect analysis. The snowfall samples exhibited a strong positive correlation between the air temperature and isotopic values $\left(\delta \mathrm{D}_{-} \mathrm{T}_{\text {air }}, r=0.850\right.$, $p<0.05, \delta^{18} \mathrm{O}-\mathrm{T}_{\text {air }}, r=0.821, p<0.05, N=7$, Fig. 5a); however, no correlation was found for the rainfall samples $\left(\delta \mathrm{D}-\mathrm{T}_{\text {air }}, p=0.101, \delta^{18} \mathrm{O}-\mathrm{T}_{\text {air }}, p=0.053, N=\right.$ $25)$ or the overall period $\left(\delta \mathrm{D}-\mathrm{T}_{\text {air }}, p=0.390, \delta^{18} \mathrm{O}-\mathrm{T}_{\text {air }}\right.$, $p=0.239, N=32$ ).

A negative correlation existed between the precipitation amount and isotopic values during the monsoon season (June to August) ( $\delta \mathrm{D}-\mathrm{P}_{\text {amount, }}$ $r=-0.658, p<0.01, \delta^{18} \mathrm{O}-\mathrm{P}_{\text {amount }}, r=-0.661, p<0.01, N=16$, Fig. 5b), but this correlation was non-significant for the overall period $\left(\delta \mathrm{D}-\mathrm{P}_{\text {amount }}, p=0.104, \delta^{18} \mathrm{O}-\mathrm{P}_{\text {amount }}\right.$, $p=0.111, N=32$ ). Based on these results, the temperature effect and amount effect occurred in the snow season (before mid-May) and monsoon season (June to August), respectively.

\section{Moisture Source Contributions}

The Hybrid Single-Particle Lagrangian Integrated Trajectory Model (HYSPLIT4) results determined that the primary moisture source pathways were from the Westerly winds in April, the Pacific Ocean in July, and the Indian Ocean in September (Fig. 6).

In early spring, the air masses arriving at Luya Mountain were principally sourced from Westerly winds, Polar air mass, and local evaporation (Fig. 6a, b). From June to July, increased Pacific Ocean moisture influence on Luya Mountain occurred which carried large precipitation amounts (Fig. 6c-e). In August, due to the weakening of the subtropical anticyclones, the northward advance of the East Asian summer monsoon was hindered by the northern inland air mass (Fig. 6f), resulting in a $33 \%$ precipitation decrease than the longterm mean for that month (Fig. 2). In September, the Indian Ocean transported via South Asian summer monsoon was the predominant moisture source, with secondary sources from the inland recycled moisture (Fig. 6g, h). 

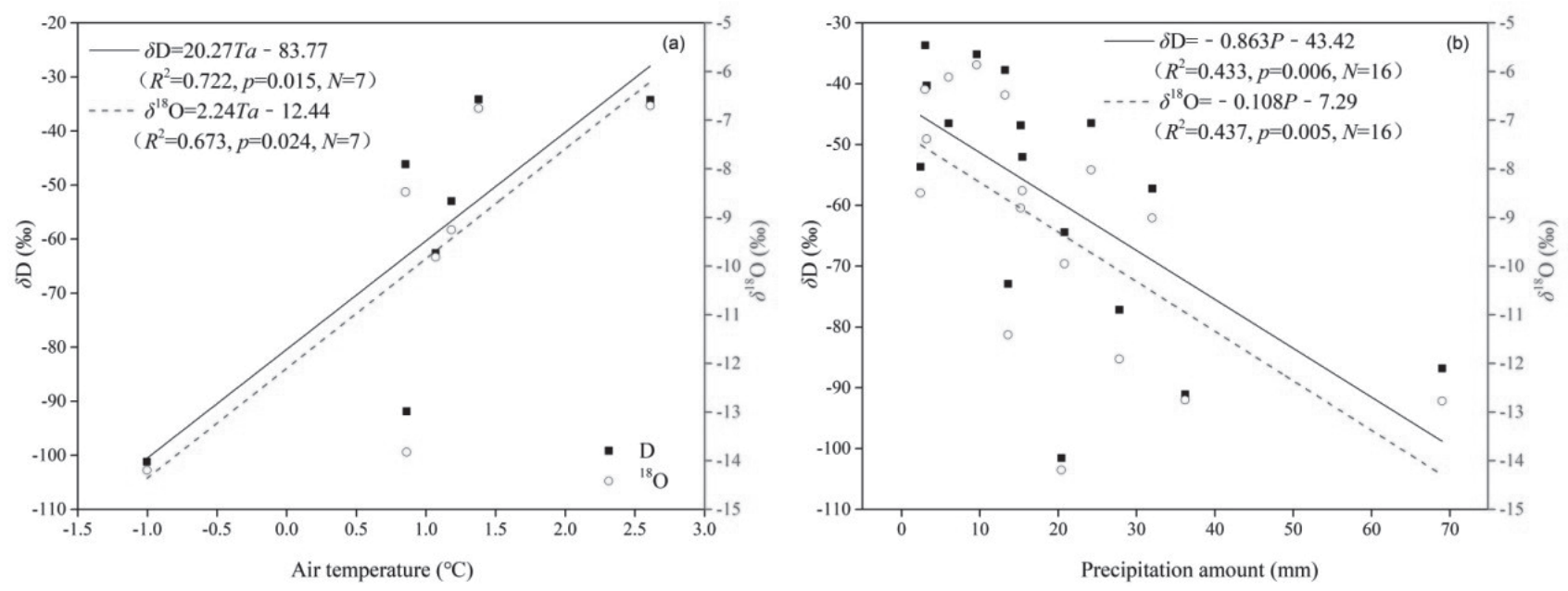

Fig. 5. a) Correlations between daily mean air temperature and $\delta \mathrm{D}$ and $\delta^{18} \mathrm{O}$ in the snowfall period from 13 April-10 May, 2014. b) Correlations between precipitation amounts and $\delta \mathrm{D}$ and $\delta^{18} \mathrm{O}$ during the monsoon season from June to August. The black solid and red dash regression lines represent the precipitation data and the correlation significance for $\delta \mathrm{D}$ and $\delta^{18} \mathrm{O}$, respectively. The air temperature was averaged by the daily mean air temperature for each sample interval. The precipitation amount is the sum of the precipitation amounts for each sample interval.
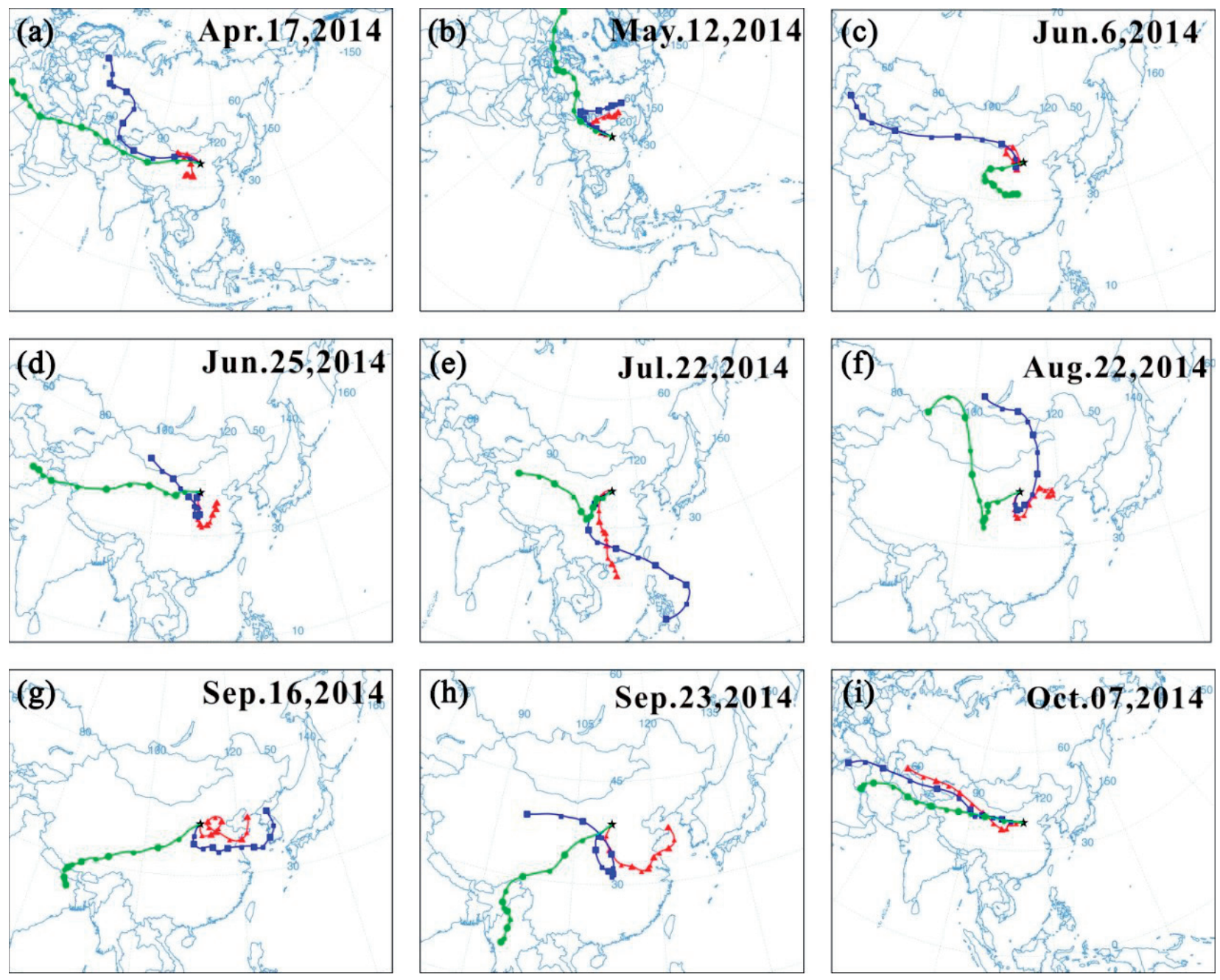

Fig. 6. Air-mass trajectory estimates for precipitation in selected sample period. The solid red, blue, and green lines represent 850, 700, and $500 \mathrm{hPa}$ air mass trajectory pressures, respectively. Star represents the study site. 


\section{Discussion}

\section{Stable Isotope Composition and LMWL}

The stable isotope values in the Luya Mountain precipitation exhibited strong seasonal variations (Table S1). Generally, these variation ranges are consistent with those of the CHNIP [20]. The slope of LMWL (7.95) in our study was much higher than those of city stations in North China (Table 1); however, it was similar to the slope of GMWL (8), which might be because most of the stations in North China, such as Beijing and Taiyuan, have a mid-latitude continental climate. In a relatively dry climate, the falling raindrops quickly evaporate via kinetic fractionation, which decreases the slope [43]. In contrast, our study site is located in an alpine ecosystem with a low annual air temperature $\left(-1.0^{\circ} \mathrm{C}\right)$ and moist conditions (69\% relative humidity); therefore, the vapor is expected to be in equilibrium with the ocean water, resulting in an approximate slope of 8 . This agrees with previous study results preformed in the Fen River headwater catchment region that determine the slope of LMWL was 7.86 [42].

\section{High $d$-excess Values in Precipitation Caused by Secondary Evaporation}

Precipitation in the Luya Mountain had a high $d$-excess value of $16.09 \%$ compared to the global average of $10 \%$. The observations in our study agree with Yang et al. [42], who reported that precipitation in the subalpine meadow zone of the same region has high $d$-excess values ranging from $15.59-17.20 \%$. The $d$-excess value reflects kinetic fractionation processes occurring during water evaporation at a lower humidity or the re-evaporation of previously condensed water vapor (i.e., secondary evaporation) [4, 18]. Due to the high humidity at Luya Mountain, the high $d$-excess values observed in this study are probably caused by reevaporated water, which is consistent with the $d$-excess values previously reported in mountain ecosystems [27,
43]. Cui et al. [25] found that the $d$-excess values of precipitation in the Wolong alpine meadow was $34.70 \%$, and secondary evaporated water contributed $40 \%$. In the middle of the Tibetan Plateau, locally recycled moisture significantly impacts the regional circulation precipitation and the local recycling ratio increased from $30 \%$ to $80 \%$ [44].

The environmental conditions in Luya Mountain are conducive to local water recycling. The Fen River headwater catchment is supplied by a series of alpine lakes from the Quaternary remnant of the glaciations [45], and the vegetation coverage in this area is high, with a canopy density of 0.8 [46]. Therefore, water evaporation pools, including evaporation from open water bodies and soil water, and plant transpiration pools, act as secondary moisture sources [47, 48]. This is supported by the evidence that the $d$-excess value decreases to a minimum of $2.41 \%$ (July 19) after 15 consecutive rain days in the monsoon season (Fig. 3). Furthermore, high relative humidity may indicate moisture exchange between the saturated atmosphere moisture and evaporating falling raindrops in mountain ecosystems, resulting in high rain $d$-excess values [49]. The higher $d$-excess values that occur in fog compared with those occurring in local rain have been documented in hydrological studies in mountain ecosystems [50]. Based on these results, the precipitation in the Luya alpine ecosystem is contributed by multiple moisture sources from local secondary evaporation and is characterized by high $d$-excess values.

\section{Seasonal Variability of Temperature and Precipitation Amount Effects}

The isotope-air temperature relationships have been widely studied [18], and most studies showed higher isotopic values in precipitation with increased temperature. However, our study determined that the temperature effect varies based on the time of year and found a significant effect only in the cold snow period (April to May). A possible explanation for this

Table 1. The meteoric water line for some nearby sites in China.

\begin{tabular}{|c|c|c|c|c|c|c|}
\hline Site (Time period) & $\begin{array}{c}\text { Altitude } \\
(\mathrm{m})\end{array}$ & Latitude & Longitude & Local Meteoric Water Line & $\begin{array}{c}\text { Data } \\
\text { source }\end{array}$ & Reference \\
\hline Taiyuan (1986-1988) & 778 & 37.78 & 112.55 & $\delta \mathrm{D}=6.42 \delta^{18} \mathrm{O}-4.66\left(R^{2}=0.95\right)$ & GNIP & Deng et al. [40] \\
\hline Baotou (1986-1992) & 1067 & 40.67 & 109.85 & $\delta \mathrm{D}=6.42 \delta^{18} \mathrm{O}-4.07\left(R^{2}=0.97\right)$ & GNIP & Deng et al. [40] \\
\hline Beijing (2011-2012) & 1248 & 39.96 & 115.43 & $\delta \mathrm{D}=6.42 \delta^{18} \mathrm{O}-5.91\left(R^{2}=0.92\right)$ & Manual & Jia et al. [41] \\
\hline Shijiazhuang (1985-1988) & 80 & 38.03 & 114.42 & $\delta \mathrm{D}=6.81 \delta^{18} \mathrm{O}-1.42\left(R^{2}=0.88\right)$ & GNIP & Deng et al. [40] \\
\hline Tianjin (1988-2001) & 3 & 39.10 & 117.17 & $\delta \mathrm{D}=7.70 \delta^{18} \mathrm{O}+8.70\left(R^{2}=0.92\right)$ & GNIP & Deng et al. [40] \\
\hline $\begin{array}{c}\text { Wolong alpine meadow } \\
(2006)\end{array}$ & 3710 & 30.88 & 102.93 & $\delta \mathrm{D}=7.98 \delta^{18} \mathrm{O}+34.28\left(R^{2}=0.97\right)$ & Manual & Zhang et al. [27] \\
\hline $\begin{array}{c}\text { Fen River headwater } \\
\text { catchment (2011-2012) }\end{array}$ & $1676-2665$ & 38.78 & 111.97 & $\delta \mathrm{D}=7.86 \delta^{18} \mathrm{O}+8.68\left(R^{2}=0.94\right)$ & Manual & Yang et al. [42] \\
\hline
\end{tabular}

GNIP: Global Network of Isotopes in Precipitation 
seasonal variation is the location of Luya Mountain, a mid-latitude transitional region from monsoon to nonmonsoon climate. Liu et al. [20] conclude that in China, the temperature effect of $\delta^{18} \mathrm{O}$ in precipitation increased from south to north; however, the temperature effect is minimal during rainy summer due to increased precipitation amounts caused by the monsoon climate in North China [51]. Therefore, the temperature effect only occurs in the winter season but not in summer season or whole year in northern China [52]. Furthermore, the seasonal variation in the temperature effect could be partial explained by the seasonal shifting of the vapor sources. The temperature effect may diminish due to the predominance of convective systems during the warmer period from June to August.

A significant precipitation amount effect was observed during the rainy summer season, but not for the overall period, probably due to the huge moisture transported from low- and mid-latitudes by the summer monsoon. Generally, stronger summer monsoons are correlated with a larger negative isotope composition in precipitation, caused by less evaporation [53]. The precipitation amount effect usually occurs on islands or coastal regions [54]; however, some studies have also observed this effect in the inland regions of northwest China, which have a typical continental arid climate [55]. Gui et al. [56] reported the effect of precipitation amount was apparent only in summer and was caused by the co-influence of sub-cloud evaporation and monsoon activities. Therefore, the precipitation amount effect is not negligible during the monsoon period in the arid and semi-arid inland regions of China.

\section{South Asian Summer Monsoon Influence on Luya Mountain Precipitation}

The backward trajectories by HYSPLIT4 model indicated the precipitation in September originates from the Indian Ocean by the South Asian summer monsoon. Therefore, the model results could explain why the lowest $\delta \mathrm{D}$ and $\delta^{18} \mathrm{O}$ values of precipitation occurring in September, not in July, which latter month had the largest precipitation amounts originating from the Pacific Ocean by the East Asian summer monsoon. Because the longer transportation distance from the Indian Ocean compared with from the Pacific Ocean results in a significant decrease in the isotopic values of precipitation [57, 58]. Furthermore, when the East Asian summer monsoon advances northward inland, it primarily travels over plains or low-altitude hills, whereas the northward path of the South Asian summer monsoon is mainly obstructed by high-altitude mountains, such as the Hengduan Mountains (4000$5000 \mathrm{~m}$ a.s.1.) and Qinling Mountains (2000-3000 m a.s.1.). When the airflow climbs the mountain and condenses to form precipitation, a significant decrease in $\delta \mathrm{D}$ and $\delta^{18} \mathrm{O}$ occurs due to Rayleigh fractionation and the rainout effect $[59,60]$, called the 'altitude effect'. Previous Tibetan Plateau studies have demonstrated that precipitation from the Indian summer monsoon has extremely low isotopic values and is minimal in late summer [2]. This isotopic signature is consistent with our results derived from the moisture source trajectories and suggests that the South Asian summer monsoonal moisture reaches the Luya Mountains in September.

Lower isotopic values $\left(\delta \mathrm{D}, \delta^{18} \mathrm{O}\right.$ and $d$-excess) are expected for precipitation from long-distance transport by the westerly or monsoon [61, 62]. However, the higher $d$-excess value of precipitation in September (16.64\%o) compared to the global average value suggests that some moisture with a higher d-excess value may also significantly affect the moisture circulation in September. Thus, changes in the d-excess values were mainly governed by sub-cloud processes [36], which correspond with the secondary evaporation contribution discussed in section of "High $d$-excess values in precipitation caused by secondary evaporation". Overall, the moisture sources for most of the precipitation in September are probably a combination of the South Asian summer monsoon and local secondary evaporation.

\section{Conclusions}

This study discusses the stable isotopic signatures of precipitation and their responses to different moisture sources in an alpine meadow on Luya Mountain, a representative site in the monsoon marginal area of north-central China. Positive temperature-isotopic $\left(\delta \mathrm{D}, \delta^{18} \mathrm{O}\right)$ signature effect was observed in the snow season before mid-May. Precipitation amount effect was observed in the monsoon season from June to August; however both effects became vague for the entire period. Understanding the periodic responses of precipitation $\delta \mathrm{D}$ and $\delta^{18} \mathrm{O}$ to climatic process is essential and can improve our perception of the climate sensitivity of isotopic signals recorded in some paleoclimate proxies (e.g., tree rings, pollen, and diatoms). Therefore, during the trees growing season on Luya Mountain (early June to early September), it is posited that precipitation signals, rather than temperature signals, are deposited in the tree-ring oxygen isotopes in this region.

\section{Funding}

This work is funded by the National Natural Science Foundation of China (Grant No. 41801026 and 41401063) the China Scholarship Council (Grant No. 201908410061 and 201808410575), and Student Research Training Program (Grant No. 2021398).

\section{Acknowledgments}

We would like to thank Biao Wang, Mingchang Wang, Liang Jiao, Zhaojiang Hou, Wenyu Duan,Yan 
Wen, and Xinyuan Ding for their help in the fieldwork. The authors would also like to acknowledge the helpful and constructive suggestions and comments from the anonymous reviewers and the Editor that have improved and clarified this study.

\section{Conflict of Interest}

The authors declare no conflict of interest.

\section{References}

1. GALEWSKY J., STEEN-LARSEN H.C., FIELD R.D., WORDEN J., RISI C., SCHNEIDER M. Stable isotopes in atmospheric water vapor and applications to the hydrologic cycle. Rev. Geophys., 54 (4), 809, 2016.

2. YAO T.D., MASSON-DELMOTTE V., GAO J., YU W.S., YANG X.X., RISI C., STURM C., WERNER M., ZHAO H.B., HE Y., REN W., TIAN L.D., SHI C.M., HOU S.G. A review of climatic controls on $\delta^{18} \mathrm{O}$ in precipitation over the Tibetan Plateau: observations and simulations. Rev. Geophys., 51 (4), 24, 2013.

3. KOSTROVA S.S., MEYER H., FERNANDOY F., WERNER M., TARASOV P.E. Moisture origin and stable isotope characteristics of precipitation in southeast Siberia. Hydrol. Process., 34 (1), 51, 2020.

4. BOTTYAN E., CZUPPON G., WEIDINGER T., HASZPRA L., KARMAN K. Moisture source diagnostics and isotope characteristics for precipitation in east Hungary: implications for their relationship. Hydrol. Sci. J.-J. Sci. Hydrol., 62 (12), 2049, 2017.

5. HUANG R., ZHU H., LIANG E., GRIE INGER J., WERNICKE J., YU W., HOCHREUTHER P., RISI C., ZENG Y., FREMME A., SODEMANN H., BR UNING A. Temperature signals in tree-ring oxygen isotope series from the northern slope of the Himalaya. Earth Planet. Sci. Lett., 506, 455, 2019.

6. ARAGUÁS-ARAGUÁS L., FROEHLICH K., ROZANSKI K. Deuterium and oxygen-18 isotope composition of precipitation and atmospheric moisture. Hydrol. Process., 14 (8), 1341, 2000.

7. GAT J.R. Atmospheric water balance - the isotopic perspective. Hydrol. Process., 14 (8), 1357, 2000.

8. JUHLKE T.R., MEIER C., VAN GELDERN R., VANSELOW K.A., WERNICKE J., BAIDULLOEVA J., BARTH J.A.C., WEISE S.M. Assessing moisture sources of precipitation in the Western Pamir Mountains (Tajikistan, Central Asia) using deuterium excess. Tellus Ser. B-Chem. Phys. Meteorol., 71, 1445379, 2019.

9. HAGER B., FOELSCHE U. Stable isotope composition of precipitation in Austria. Austrian J. Earth Sci., 108 (2), 2, 2015.

10. CRAIG H. Isotopic variations in meteoric waters. Science, 133 (346), 1702, 1961.

11. BENETTIN P., VOLKMANN T.H.M., VON FREYBERG J., FRENTRESS J., PENNA D., DAWSON T.E., KIRCHNER J. Effects of climatic seasonality on the isotopic composition of evaporating soil waters. Hydrol. Earth Syst. Sci., 22 (5), 2881, 2018.

12. WANG S.J., ZHANG M.J., HUGHES C.E., ZHU X.F., DONG L., REN Z.G., CHEN F.L. Factors controlling stable isotope composition of precipitation in arid conditions: an observation network in the Tianshan Mountains, central Asia. Tellus Ser. B-Chem. Phys. Meteorol., 68, 14, 2016.

13. DOTSIKA E., LYKOUDIS S., POUTOUKIS D. Spatial distribution of the isotopic composition of precipitation and spring water in Greece. Glob. Planet. Change, 71 (34), 141, 2010.

14. ZHAO P., TANG X.Y., ZHAO P., TANG J.L. Temporal partitioning of water between plants and hillslope flow in a subtropical climate. Catena, 165, 133, 2018.

15. DANSGAARD W. Stable isotopes in precipitation. Tellus, $16(4), 436,1964$

16. JEELANI G., DESHPANDE R.D., GALKOWSKI M., ROZANSKI K. Isotopic composition of daily precipitation along the southern foothills of the Himalayas: impact of marine and continental sources of atmospheric moisture. Atmos. Chem. Phys., 18 (12), 8789, 2018.

17. LONE S.A., JEELANI G., DESHPANDE R.D., MUKHERJEE A. Stable isotope $\left(\delta^{18} \mathrm{O}\right.$ and $\left.\delta \mathrm{D}\right)$ dynamics of precipitation in a high altitude Himalayan cold desert and its surroundings in Indus river basin, Ladakh. Atmos. Res., 221, 46, 2019.

18. ISLAM M.R., GAO J., AHMED N., KARIM M.M., BHUIYAN A.Q., AHSAN A., AHMED S. Controls on spatiotemporal variations of stable isotopes in precipitation across Bangladesh. Atmos. Res., 247, 105224, 2021.

19. WEN X., LIU Z., CHEN Z., BRADY E., NOONE D., ZHU Q., GUAN J. Modeling precipitation $\delta^{18} \mathrm{O}$ variability in East Asia since the Last Glacial Maximum: temperature and amount effects across different timescales. Clim. Past., 12 (11), 2077, 2016

20. LIU J.R., SONG X.F., YUAN G.F., SUN X.M., YANG L.H. Stable isotopic compositions of precipitation in China. Tellus Ser. B-Chem. Phys. Meteorol., 66, 22567, 2014.

21. ARAGUÁS-ARAGUÁS L., FROEHLICH K., ROZANSKI K. Stable isotope composition of precipitation over southeast Asia. J. Geophys. Res., 103 (D22), 28721, 1998.

22. ZHENG S.H., HOU F.G., NI B.L. The studies of stable hydrogen and oxygen isotopes in precipitation in China. Chin. Sci. Bull., 13, 801, 1983 [In Chinese].

23. ZHANG M.J., WANG S.J. A review of precipitation isotope studies in China: Basic pattern and hydrological process. J. Geogr. Sci., 26 (7), 921, 2016.

24. YU W.S., WEI F.L., MA Y.M., LIU W.J., ZHANG Y.Y., LUO L., TIAN L.D., XU B.Q., QU D.M. Stable isotope variations in precipitation over Deqin on the southeastern margin of the Tibetan Plateau during different seasons related to various meteorological factors and moisture sources. Atmos. Res., 170, 123, 2016.

25. CUI J., AN S.Q., WANG Z.S., FANG C.M., LIU Y.H., YANG H.B., XU Z., LIU S.R. Using deuterium excess to determine the sources of high-altitude precipitation: Implications in hydrological relations between sub-alpine forests and alpine meadows. J. Hydrol., 373 (12), 24, 2009.

26. VOELKER S.L., BROOKS R., MEINZER F.C., RODEN J., PAZDUR A., PAWELCZYK S., HARTSOUGH P., SNYDER K., PLAVCOVA L., SANTRUCEK J. Reconstructing relative humidity from plant $\delta^{18} \mathrm{O}$ and $\delta \mathrm{D}$ as deuterium deviations from the global meteoric water line. Ecol. Appl., 24 (5), 960, 2014.

27. ZHANG W.G., CHENG B., HU Z.B., AN S.Q., XU Z., ZHAO Y.J., CUI J., XU Q. Using stable isotopes to determine the water sources in alpine ecosystems on the east Qinghai-Tibet plateau, China. Hydrol. Process., 24 (22), 3270, 2010. 
28. LIU J.B., CHEN J.H., SELVARAJ K., XU Q.H., WANG Z.L., CHEN F.H. Chemical weathering over the last 1200 years recorded in the sediments of Gonghai Lake, Lvliang Mountains, North China: a high-resolution proxy of past climate. Boreas, 43 (4), 914, 2014.

29. XU M., MA L., JIA Y., LIU M. Integrating the effects of latitude and altitude on the spatial differentiation of plant community diversity in a mountainous ecosystem in China. PLoS ONE, 12 (3), e0174231, 2017.

30. LI Q., LIU Y., SONG H.M., YANG Y.K., ZHAO B.Y. Divergence of tree-ring-based drought reconstruction between the individual sampling site and the Monsoon Asia Drought Atlas: an example from Guancen Mountain. Sci. Bull., 60 (19), 1688, 2015.

31. JIANG Y., ZHANG Y.P., GUO Y.Y., KANG M.Y., WANG M.C., WANG B. Intra-annual xylem growth of Larix principis-rupprechtii at its upper and lower distribution limits on the Luyashan mountain in north-central China. Forests, 6 (11), 3809, 2015.

32. WU H.W., ZHANG X.P., LI X.Y., LI G., HUANG Y.M. Seasonal variations of deuterium and oxygen-18 isotopes and their response to moisture source for precipitation events in the subtropical monsoon region. Hydrol. Process., 29 (1), 90, 2015.

33. ZHANG Y.P., JIANG Y., WANG B., JIAO L., WANG M. Seasonal water use by Larix principis-rupprechtii in an alpine habitat. For. Ecol. Manage., 409, 47, 2018.

34. COPLEN T.B. Guidelines and recommended terms for expression of stable-isotoperatio and gas-ratio measurement results. Rapid Commun. Mass Spectrom., 25, 2538, 2011.

35. DRAXLER R.R., ROLPH G.D. HYSPLIT (HYbrid Single-Particle Lagrangian Integrated Trajectory) Model access via NOAA ARL READY Website 2015; Available from: (http://ready.arl.noaa.gov/HYSPLIT.php).

36. CASELLAS E., LATRON J., CAYUELA C., BECH J., UDINA M., SOLA Y., LEE K.O., LLORENS P. Moisture origin and characteristics of the isotopic signature of rainfall in a Mediterranean mountain catchment (Vallcebre, eastern Pyrenees). J. Hydrol., 575, 767, 2019.

37. STEIN A.F., DRAXLER R.R., ROLPH G.D., STUNDER B.J.B., COHEN M.D., NGAN F. NOAA's HYSPLIT atmospheric transport and dispersion modeling system. 96 (12), 2059, 2015

38. SONG C.L., WANG G.X., LIU G.S., MAO T.X., SUN X.Y., CHEN X.P. Stable isotope variations of precipitation and streamflow reveal the young water fraction of a permafrost watershed. Hydrol. Process., 31 (4), 935, 2017.

39. SUN G.R., LI Y.Y., LI S.C. The differences in cloud vertical structures between active and break spells of the East Asian summer monsoon based on CloudSat data. Atmos. Res., 224, 157, 2019.

40. DENG W.P., YU X.X., JIA G.D. Sources and stable isotope characteristics of precipitation in North China. Bull. Min. Petro. Geoch., 31 (5), 489, 2012 [In Chinese].

41. JIA G.D. Water movement mechanism of plant-soil system using stable hydrogen and oxygen isotope technology. 2013, Beijing Forestry University.

42. YANG Y.G., LI C.M., QIN Z.D., ZOU S.B. Hydrologic processes of the different landscape zones in Fenhe River headwater catchment. Environ. Sci., 35 (6), 2108, 2014 [In Chinese].

43. WEN X.F., ZHANG S.C., SUN X.M., YU G.R., LEE X. Water vapor and precipitation isotope ratios in Beijing, China. J. Geophys. Res.-Atmos., 115, D01103, 2010.
44. LI L., GARZIONE C.N. Spatial distribution and controlling factors of stable isotopes in meteoric waters on the Tibetan Plateau: Implications for paleoelevation reconstruction. Earth Planet. Sci. Lett., 460, 302, 2017.

45. MENG X.G., ZHU D.G., SHAO Z.G., YU J., HAN J.E., MENG Q.W. Discovery of Quaternary remnants of glaciation in the northern segment of the Lvliang Mountains, Ningwu, Shanxi, and their significance. J. Geomec., 10 (4), 327, 2004 [In Chinese].

46. ZHANG Y.P., JIANG Y., WEN Y., DING X.Y., WANG B., $\mathrm{XU}$ J.L. Comparing primary and secondary growth of cooccurring deciduous and evergreen conifers in an alpine habitat. Forests, 10 (7), 574, 2019.

47. CHEN F.L., ZHANG M.J., ARGIRIOU A.A., WANG S.J., ZHOU X., LIU X.Y. Deuterium excess in precipitation reveals water vapor source in the monsoon margin sites in Northwest China. Water, 12 (12), 3315, 2020.

48. PENG T.R., WANG C.H., HUANG C.C., FEI L.Y., CHEN C.T.A., HWONG J.L. Stable isotopic characteristic of Taiwan's precipitation: A case study of western Pacific monsoon region. Earth Planet. Sci. Lett., 289 (3-4), 357, 2010.

49. PANG Z.H., KONG Y.L., FROEHLICH K., HUANG T.M., YUAN L.J., LI Z.Q., WANG F.T. Processes affecting isotopes in precipitation of an arid region. Tellus Ser. B-Chem. Phys. Meteorol., 63 (3), 352, 2011.

50. LI Z.X., QI F., SONG Y., WANG Q.J., YANG J., LI Y.G., LI J.G., GUO X.Y. Stable isotope composition of precipitation in the south and north slopes of Wushaoling Mountain, northwestern China. Atmos. Res., 182, 87, 2016.

51. CUI B.L., LI D.S., JIANG B.F., WANG Y., WANG Y.X., WANG L.S., LI X.Y. Stable isotopes and chloride ion of precipitation events in the northeastern Tibetan Plateau, China. J Mt. Sci., 18 (4), 834, 2021.

52. YANG X.X., YAO T.D. Different sub-monsoon signals in stable oxygen isotope in daily precipitation to the northeast of the Tibetan Plateau. Tellus Ser. B-Chem. Phys. Meteorol., 68, 15, 2016.

53. WERNICKE J., HOCHREUTHER P., GRIESSINGER J., ZHU H., WANG L., BRAUNING A. Air mass origin signals in $\delta^{18} \mathrm{O}$ of tree-ring cellulose revealed by backtrajectory modeling at the monsoonal Tibetan Plateau. Int. J. Biometeorol., 61 (6), 1109, 2017.

54. JOHNSON K.R., INGRAM B.L. Spatial and temporal variability in the stable isotope systematics of modern precipitation in China: implications for paleoclimate reconstructions. Earth Planet. Sci. Lett., 220 (3), 365, 2004.

55. LI Z.X., GAO Y., WANG Y.M., PAN Y.H., LI J.G., CHEN A.F., WANG T.T., HAN C.T., SONG Y.X., W. H. T. Can monsoon moisture arrive in the Qilian Mountains in summer? Quat. Int., 358, 113, 2015.

56. GUI J., LI Z.X., FENG Q., YUAN R.F., NING T.T., ZHANG B.J., XUE J., GAO W.D., NAN F.S., DING W.X., YANG A.L., LIANG P.F. Environmental effect and spatiotemporal pattern of stable isotopes in precipitation on the transition zone between the Tibetan Plateau and arid region. Sci. Total Environ., 749, 23, 2020.

57. TAN M. Circulation effect: response of precipitation $\delta^{18} \mathrm{O}$ to the ENSO cycle in monsoon regions of China. Clim. Dyn., 42 (3-4), 1067, 2014.

58. YU W.S., YAO T.D., THOMPSON L.G., JOUZEL J., ZHAO H.B., XU B.Q., JING Z., WANG N., WU G., MA Y., GAO J., YANG X., ZHANG J., QU D. Temperature signals of ice core and speleothem isotopic records from 
Asian monsoon region as indicated by precipitation $\delta^{18} \mathrm{O}$. Earth Planet. Sci. Lett., 554, 116665, 2021.

59. TANG Y., PANG H., ZHANG W., LI Y., WU S., HOU S. Effects of changes in moisture source and the upstream rainout on stable isotopes in precipitation - a case study in Nanjing, eastern China. Hydrol. Earth Syst. Sci., 19 (10), 4293, 2015.

60. WINNICK M.J., CHAMBERLAIN C.P., CAVES J.K., WELKER J.M. Quantifying the isotopic 'continental effect'. Earth Planet. Sci. Lett., 406, 123, 2014.

61. DU W.T., KANG S.C., QIN X., JI Z.M., SUN W.J., CHEN J.Z., YANG J.H., CHEN D.L. Can summer monsoon moisture invade the Jade Pass in Northwestern China? Clim. Dyn., 55 (11-12), 3101, 2020.

62. ADHIKARI N., GAO J., YAO T.D., YANG Y.L., DAI D. The main controls of the precipitation stable isotopes at Kathmandu, Nepal. Tellus Ser. B-Chem. Phys. Meteorol., 72 (1), 1, 2020.

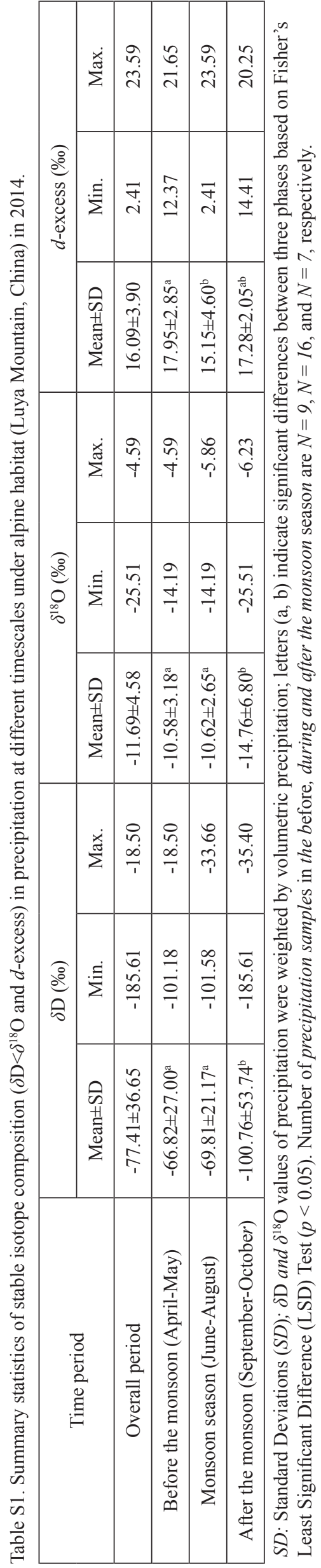

